\title{
ANALYSIS OF THE ENERGY MIX OF SLOVAKIA IN THE CONTEXT OF IMPROVEMENT OF QUALITY OF THE ENVIRONMENT
}

The contribution is focused on the trends of energy balance of Slovakia that is the key indicator determining the consumption of fuelbased energy sources accepting the principles of sustainable development and improving the quality of the environment. It refers to the development of pollutants release from the energy industry in the production of electricity and thermal energy referring to the potential use of RES in the energy mix the composition of which is in direct interaction not only with the development of the environmental load of the components of the environment but also with energy security and energy independence of Slovakia.

Keywords: Fuel-based energy resources, renewable energy sources, energy mix

\section{Introduction}

The field of the energy mix and its prediction is a topical issue which is the subject of much debate not only in Slovakia but also worldwide mainly due to the increase of the environmental protection and the need to replace exhaustible energy sources by renewable resources.

The energy sector is one of segments significantly contaminating the environment. An integral part of the scientific projections of anthropogenic society is also the problem of ensuring sufficient energy while ensuring a quality environment. Total energy consumption and energy structure of the Slovak economy is one of the limiting factors of energy impact on the environment. It is therefore essential to ensure harmonious relationship of energy and the environment through an introduction of appropriate technologies that will in particular use renewable energy sources (hydro, wind, solar, geothermal, tidal energy, etc.) and the conventional energy technologies will be equipped with environmental protection devices with high efficiency. All energy sources must be used in a way that takes into account both human health and the environment and its quality.

\section{Consumption of fuel-based energy sources and their} influence on the quality of the environment in Slovakia

Energy sources that constitute the energy mix are crucial in ensuring the needs, living standard and overall development of human society. The current evolution of social energy consumption refers to the fact that the most used seems to be electric energy which is also the most common type of energy for present and future economic development of Slovakia. Dominant forms of power generation are thermal and nuclear power whose common feature is so called thermal environmental contamination resulting from the relatively low conversion efficiency of thermal energy into electricity [1]. The projected development and consumption of electricity after commissioning of the third and fourth blocks of Mochovce nuclear power plant and the planned construction of renewable energy sources (RES) energy balance should be invoked in the time span around 2013. The planned energy mix of Slovakia includes a larger share of nuclear energy in the future. The relatively low share of RES is the reason for this situation. Binding objective of Slovakia by 2030 is to achieve a minimum of $14 \%$ share of RES in final energy consumption [2].

Thermal power plants burn fossil fuels and in this process a wide range of airborne contaminants, for example, harmful compounds of sulphur, arsenic, selenium, tellurium, mercury, lead, cadmium and other toxic active substances (including organic compounds that are carcinogenic or teratogenic in certain cases) are produced. The adverse effects on the environment are most negatively manifested by gaseous contamination (the most serious is $\mathrm{SO}_{2}$ ) and solid emissions (fly ash). Fly ash can be captured with high efficiency but $\mathrm{SO}_{2}$ is a major problem especially in the atmosphere where it reacts with other components and secondarily contaminates the soil and water resources [3].

Nuclear power plants operate on a similar principle as thermal power plants, i.e., obtain energy by transforming thermal energy into electricity. Fission of uranium $\mathrm{U}^{235}$ to neutrons in a nuclear reactor creates a large amount of heat used for steam production which drives the steam turbine generators. In addition to the residual heat (cooling by water) no further emissions are created so

\footnotetext{
* Barbara Hlavnova ${ }^{1}$, Milena Svitekova ${ }^{2}$, Jana Simonidesova ${ }^{3}$

${ }^{1}$ Institute of Geoturism, Faculty of Mining, Ecology, Process control and Geotechnology, Technical University of Kosice, Slovakia, E-mail: barbara.hlavnova@tuke.sk

${ }^{2}$ Department of Communications, Faculty of Operation and Economics of Transport and Communications, University of Zilina, Slovakia

${ }^{3}$ Department of Finance and Accounting, Faculty of Business Economy, University of Economics in Bratislava, Slovakia
} 
some experts prefer this method of electricity production to incineration if trouble-free plant operation is ensured. In some countries this method of electricity production is dominant (France, Japan). In terms of environmental contamination the spent fuel is dangerous because of radioactive waste and the activated parts of nuclear power after termination of the operation. By nuclear power plants more than $52 \%$ of electricity is currently produced in Slovakia. Nuclear fuel supply is ensured by long-term contracts from the Russian Federation. It is useful to support the transition to improved fuel with better use of nuclear material in nuclear fuel which results in a reduction of its consumption. In connection to the use of nuclear fuel for electricity generation resolution of the problem of storage of spent nuclear fuel as well as the question of decommissioned nuclear facilities is a key issue. In addressing the issues in this field Slovakia is in line with the EU [1]

The primary problem of the Slovak energy sector is the high up to about $90 \%$ dependence on imported fuel-based energy sources (FES - including nuclear fuel) from abroad as due to the natural conditions and the current technological possibilities there are very low levels of these resources in Slovakia. Domestic sources of fossil fuels include only brown coal and lignite. A similar situation exists in liquid ( $2 \%$ of own resources) and gas ( $3 \%$ of own resources) energy sources. Hydropower and biomass are the most involved RES in primary production [1 and 4].

The structure of the FES in the SR is characterized by reduced consumption of solid and gaseous fuels and heat, whereas increased consumption of liquid fuels, electricity and renewable energy sources in the period from 2001 to 2010 (Fig. 1).

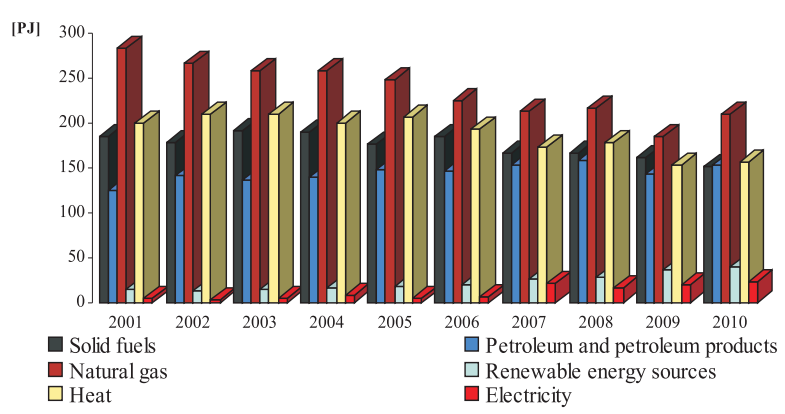

Fig. 1 Development of consumption of particular types of primary energy sources by fuel type Source: Prepared according to SAZP, $2000-2011$

Consumption of solid fuels gradually declined during the monitored period by nearly $19 \%$. Consumption of gaseous fuels declined by $26 \%$ with slight fluctuation in 2010 compared to 2001 . The liquid fuel consumption increased by $18 \%$ for the same period. The consumption of RES increased by about $62 \%$ in 2010 compared to 2001. The most significantly increased the consumption of electricity by more than $80 \%$ in the last 10 years. An extremely important role in the structure of primary energy sources plays the use of nuclear fuel in Slovakia in recent years. Due to the replacement of petroleum products with biofuels only a slight increase in petroleum consumption is expected especially in transport.

Domestic brown coal currently accounts for approximately $79 \%$ of the consumption of brown coal needed to produce electricity and heat. It plays an important role in ensuring security of electricity supply. The rest of the necessary amount of brown coal and all the black coal are imported. A gradual decline is expected in the brown coal mining and in the long term brown coal mining can not be considered sufficient to meet the needs of electricity and heat production. Domestic coal, however, remains the only nonrenewable resource needed to ensure the system reliability. Consumption of natural gas was about 5.7 billion $\mathrm{m}^{3}$ in Slovakia in 2010 which represents an annual increase of about $6.5 \%$. The domestic mining contributes by about $2 \%$ to this consumption. The rest of the natural gas is imported from Russia. The increase in natural gas consumption has caused economic recovery after the global financial crisis which started in January 2009. The share of the Slovak Gas Company, Inc. (SPP) on the gas supply on the total gas supply to industrial customers was $79 \%$. The gas market in 2010 entered a new phase when other companies entered the market of gas suppliers to industrial consumers. Their share was $21.5 \%$ of all the gas supplied, thus it increased threefold compared to 2009. The share of natural gas in primary energy sources is expected to decline moderately by 2013 or more precisely 2030 but it still would be above the EU average [5]. Slovakia imports about 5.5 million $t$ of petroleum annually. This volume is guaranteed by a long-term international agreement with the Russian Federation. 3.2 million $t$ of the imported petroleum amount is used to meet the domestic consumption. Domestic extraction takes a share of less than $2 \%$ in oil consumption

Currently, about 4.7 TWh of electricity is produced by RES including hydro power potential of large hydropower plants - representing approximately $17 \%$ of gross final energy consumption of electricity. Biomass is the most promising renewable source for heat generation with total annual potential of about 75.6 PJ suitable for energy production. Biomass is also a promising source of electricity generation [1 and 4].

The development of final energy consumption showed a declining trend in the monitored period till 2007 (drop by nearly 13.4\% compared to 2001). In 2008, the final consumption increased by more than $2 \%$ compared to the previous year. In 2010, it increased by nearly $7.8 \%(418,853 \mathrm{TJ})$ compared to the previous year and almost reached the 2008 level of 418291 TJ (Fig. 2). In 2010, the largest share of total consumption was represented by industry (32\%), followed by three sectors: households (23\%), transport $(22.5 \%)$ and trade and services (21\%). The lowest share of only $1.3 \%$ was represented by the agricultural sector. There is an upward trend in the transport sector in the monitored period with consumption increased by $35 \%$ over the last 10 years. Since 2001 the consumption in other sectors has been declining with the exception of trade and services sector in which the consumption was less than 1\% higher in 2010 than in 2001. 


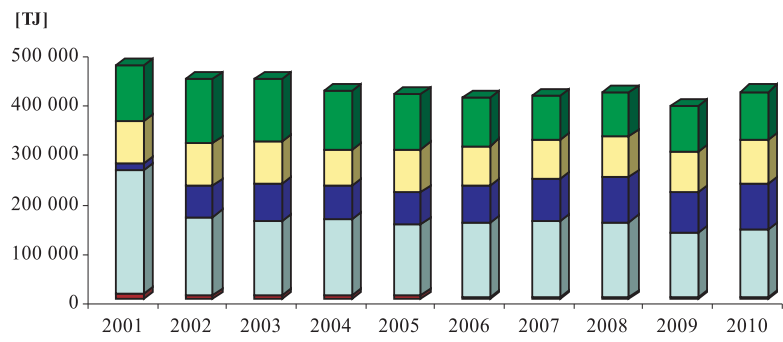

$\square$ Agriculture $\square$ Industry $\square$ Transport $\square$ Trade and services $\square$ Households

Fig. 2 Development of final energy consumption in different sectors of Slovak economy

Source: Prepared according to SAZP, 2000 - 2011

Industry showed the largest share of consumption of selected FES (Fig. 3) in Slovakia in 2010. From 2001 to 2010 the consumption of gaseous fuels and the consumption of fossil fuels declined by about $42 \%$ and $20 \%$ respectively in the industry. On the contrary the consumption of liquid fuels increased by about $20 \%$. Since 2001 it is also possible to monitor the consumption of RES and wastes, the most used are wood and industrial waste (an increase of about $67 \%$ ). Consumption of solid fuels in agriculture dropped significantly (about $81 \%$ ). Brown coal and lignite show the highest consumption of solid fuels. Petroleum shows the highest consumption of liquid fuels (nearly $97 \%$ share) while in the period from 2000 to 2010 the overall consumption decreased by nearly $33 \%$. The most consumed gaseous fuel - natural gas - decreased by about $29 \%$ during the whole monitored period. The final consumption of RES and waste are the most influenced by the consumption of wood, industrial waste and biogas. In the transport sector the consumption of gaseous fuels increased most notably (by almost 100\%), the consumption of liquid fuels also increased (by $25 \%$ ), and the final consumption of solid fuels decreased (by almost $90 \%$ ) in the period of $2001-2010$ [1].

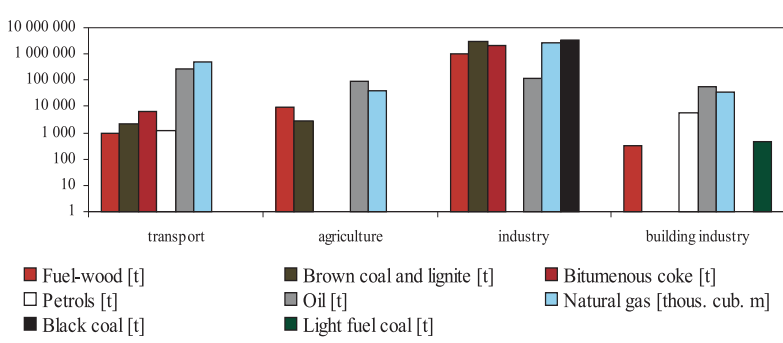

Fig. 3 Consumption of selected FES in certain sectors of Slovakia in 2010 Source: Prepared according to SU SR, 2000 - 2011 Note 1: Not all FES are used in particular sectors. Note 2: Logarithmic axis is used.

The energy sector is one of the sectors most negatively affecting the environment and human health. The energy sector as the largest emitter of greenhouse gases mainly carbon dioxide, methane but also nitrous oxide, contributes in a large extent to climate change and intensification of the greenhouse effect. Total greenhouse gas emissions in 2009 were in the amount of $43426.07 \mathrm{Gg}$ of $\mathrm{CO}_{2}$ equivalent which represented a reduction of $41.44 \%$ compared to the reference year 1990 (74 154.78 Gg of $\mathrm{CO}_{2}$ equivalent). Production of electricity and heat based on fossil fuels is accompanied by production of sulphur dioxide, oxides of nitrogen, carbon monoxide and solid pollutants. Within the protection of air greening of the resource base is important in order to reduce the production of emissions released into the air. In the period $1990-2009$ pollutant emissions from the energy sector fell sharply. The solid pollutants and sulphur dioxide emissions decreased most significantly by about $90 \%$ and $80 \%$ respectively. In 2009 compared to the reference year, the emissions of oxides of nitrogen and carbon monoxide decreased by approximately $49 \%$ and $48 \%$ respectively (Fig. 4) [1].

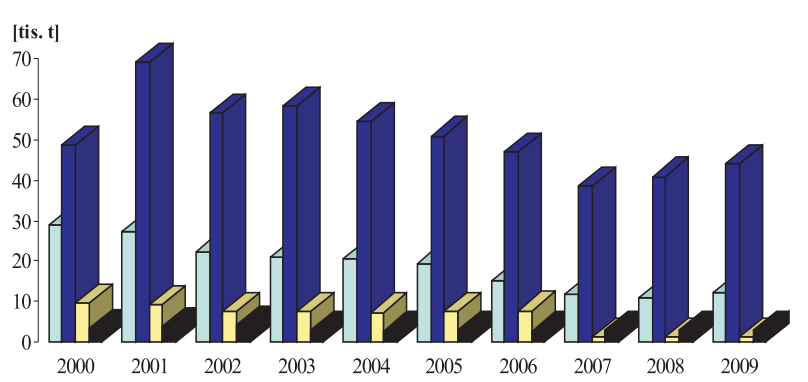

Fig. 4 Development of the emissions of major pollutants from stationary energy resources

Source: Prepared according to SAZP, 2000 - 2011

21436 thous. $\mathrm{m}^{3}$ of waste water was released to recipients from different technologies and cooling processes in 2010. Sewage contributed to a lesser extent in the released waste water. Waste water from the technologies is chemically contaminated, in case of nuclear power stations in the primary circuit also radio chemically. For the water that is used for cooling, thermal pollution is mostly significant. The contamination of sewage is mostly biologi-

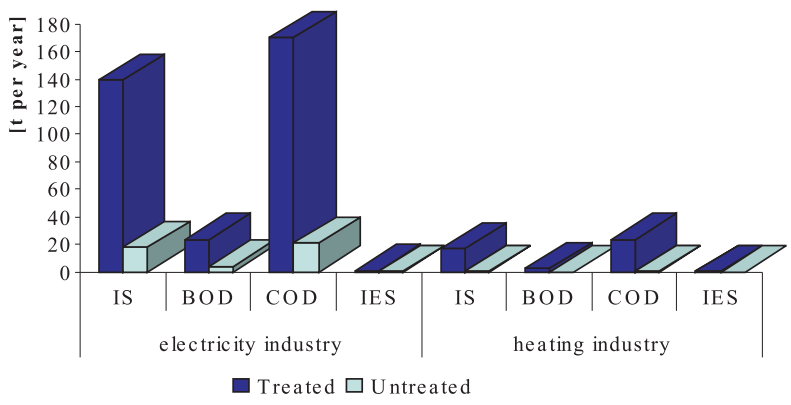

Fig. 5 Quantification of indicators of pollution in waste water from power generation in 2010

Source: Prepared according to SAZP, 2000 - 2011 
cal. The indicators of insoluble substances (IS) and COD show the greatest burden, the indicator of insoluble extractable substances (IES) show the smallest one (Fig. 5).

\section{Possibilities of the improvement of the quality of the environment}

From the above information on the consumption of FES and the composition of the energy mix results that minimization of the negative environmental impacts can be achieved by increasing the share of renewable energy. In this way it is also possible to increase the energy independence of Slovakia which should also be strategically important for the economic success of the country. Even in the use of RES it is important to ensure the continuity of energy supplies to a consumer which requires a correct combination of renewable and non-renewable energy sources. One of the best combinations is the combination of solar energy and natural gas. It is not possible to clearly identify the most suitable FEZ for increase of the quality of the environment while maintaining the satisfaction of needs of human society. New technologies are constantly emerging on the market which contribute to greater environmental protection thus it can not be clearly stated which FES is the most advantageous in this respect. Nevertheless, particular FES can be compared taking into account their negative impacts on the environment (Table 1).

A comparison of the negative impacts

Tab. 1 of FES on the environment

\begin{tabular}{|c|c|c|c|}
\hline FES & Emissions & Solid waste & Reserves \\
\hline Sun & - & - & unlimited \\
\hline Wind & - & - & unlimited \\
\hline Hydro & - & - & unlimited \\
\hline Geothermal & - & - & unlimited \\
\hline Biomass & - & - & unlimited \\
\hline Nuclear & $\begin{array}{c}\text { indirect } \\
\text { emissions* }\end{array}$ & $\begin{array}{l}\text { radioactive } \\
\text { waste }\end{array}$ & \\
\hline hot water & $\begin{array}{c}\text { approx. } 270 \\
\text { years }\end{array}$ & & \\
\hline Coal & $\begin{array}{c}\mathrm{CO}_{2}, \mathrm{Hg}, \mathrm{NO}_{\mathrm{X}} \\
\mathrm{SO}_{\mathrm{X}}\end{array}$ & slag & $\begin{array}{l}\text { approx. } 2 \text { cent. } \\
\text { or more }\end{array}$ \\
\hline Petroleum & $\begin{array}{l}\mathrm{SO}_{\mathrm{X}}, \mathrm{CH}_{4} \\
\mathrm{CO}_{\mathrm{X}}, \mathrm{NO}_{\mathrm{X}}\end{array}$ & waste oil & 40 to 50 years \\
\hline Natural gas & $\mathrm{CH}_{4}, \mathrm{CO}_{2}, \mathrm{NO}_{\mathrm{X}}$ & - & approx. 2 cent. \\
\hline
\end{tabular}

* Indirect emissions - from the extraction, transport and processing of uranium, but also in the construction and decommissioning of a nuclear power plant

An increase of the share of RES in electricity and heat energy production would definitely contribute to reducing the environmental burden caused by the energy sector as the production of green- house gases, solid pollutants and, of course, the heat pollution would decrease. The use of RES in energy mix of Slovakia is determined by the so-called technically exploitable potential of RES the value of which has been estimated at $136421 \mathrm{GWh}$ per year while currently only $30 \%$ being used (Table 2 ). Biomass from agricultural production has the highest technically exploitable potential of all RES (6 $300 \mathrm{GWh}$ per year) and sludge from wastewater treatment plants has the lowest one (230 GWh per year). At present, about $19 \%$ of domestic electricity consumption is produced by RES. The total exploitable potential of particular RES allows increasing their share in total electricity generation to $24 \%$ in 2020 and $27 \%$ in 2030. The prognosis of RES use in electricity production expects this production reaching nearly $8000 \mathrm{GWh}$ per year in 2020 with predicted largest share of electricity being produced by hydropower (large hydropower stations of above $10 \mathrm{MW}$ ) and smallest share by photovoltaic power plants. The prognosis of RES use in heat production expects this production reaching nearly 35 PJ in 2020 with predicted largest share of the heat production by solid biomass and smallest by heat pumps [6 and 7].

Technically exploitable potential of RES in Slovakia

Tab. 2

\begin{tabular}{|c|c|c|c|}
\hline \multirow[t]{2}{*}{ RES } & $\begin{array}{c}\text { Technically } \\
\text { exploitable } \\
\text { potential }\end{array}$ & $\begin{array}{c}\text { Present } \\
\text { exploitation }\end{array}$ & $\begin{array}{c}\text { Unused } \\
\text { potential }\end{array}$ \\
\hline & \multicolumn{3}{|c|}{ [GWh per year] } \\
\hline Geothermal energy & 6300 & 340 & 5960 \\
\hline Wind energy & 605 & 0 & 605 \\
\hline Solar energy & 5200 & 7 & 5193 \\
\hline Small hydropower plant & 1034 & 202 & 832 \\
\hline Biomass & 16794 & 3192 & 13602 \\
\hline $\begin{array}{c}\text { Forest biomass } \\
\text { till } 2010 \\
\text { after } 2010\end{array}$ & $\begin{array}{l}2828 \\
5623\end{array}$ & 494 & 2334 \\
\hline Wood-processing industry & 4881 & 2638 & 1880 \\
\hline Agricultural biomass & 6586 & 60 & 6526 \\
\hline Energy utilisation of waste & 3535 & 1251 & 2284 \\
\hline Wastewater sludge & 230 & 13 & 217 \\
\hline Municipal solid waste & 1775 & 368 & 1407 \\
\hline Other waste & 1530 & 870 & 660 \\
\hline Biological fuels & 2500 & 330 & 2170 \\
\hline Hydropower plants & 6607 & 5093 & 1514 \\
\hline Sum: & 37895 & 10415 & 27480 \\
\hline
\end{tabular}

Source: National Action Plan for Renewable Energy, 2010 [7]

As mentioned earlier, biomass has a relatively high potential for energy recovery in Slovakia. It can be treated by cogeneration that can continuously produce electricity and thermal energy which is considered to be $\mathrm{CO}_{2}$ negative. Fermented biogas is characterized by a relatively high content of methane (50-60\%) making its 
calorific value in range around $22 \mathrm{MJ}$ per cubic metre. Moreover, its energy use contributes to reducing emissions and the greenhouse effect. When using biomass in combination with some non-renewable types of energy, for example natural gas, the production of solid pollutants sulphur dioxide could be eliminated thereby it would also contribute to prevention of subsequent reduction of soil acidity or the $\mathrm{pH}$ values of water resources and other types of secondary pollution. This would also contribute to the use of domestic FES for electric and thermal energy production in an economically efficient principle otherwise the unused biomass presents waste mostly disposed to landfill in Slovakia. It would also provide an appropriate additional source of heat and electricity to meet the domestic consumption thereby it would also contribute to the energy independence of Slovakia and thus an increase of the energy independence of Slovakia.

\section{Conclusion}

The composition of the energy mix determines the pollution of the components of the environment hence its overall environ- mental quality. Production of energy from non-renewable FES contributes significantly to air pollution especially by greenhouse gases, burdens the water sources (both withdrawal and the pollution generated) and causes the acidification of the environment. And it is why the energy mix in an interaction with total energy consumption presents a limiting factor of negative impact of energy sector on the environment. A gradual increase of the share of RES in energy production would both ensure a way that takes human health, which is an integral part of the environment in the close interaction with its individual components into account and accept the rules and principles of sustainable development of the environment. It should also be noted, however, that an exclusive use of RES for energy needs is not possible because of a need for continuous provision of energy supplies. This, therefore, requires a combination of renewable and non-renewable resources making it possible to ensure a continuous supply of energy and at the same time it would contribute to protection of the environment by reducing greenhouse gases and solid pollutants.

\section{References}

[1] STROFFEKOVA, S.: Energetika a jej vplyv na zivotne prostredie v Slovenskej republike k roku 2009 [Energy and its Impact on the Environment in the Slovak Republic in 2009] . Indikátorova sektorova sprava. [online]. Banská Bystrica, SAZP, 2010. Available on-line: 〈http://www1.enviroportal.sk/pdf/sektor/Energetika_sektor_09.pdf>.

[2] Energeticka politika SR [Energy Policy of SR]. In: MH SR. [online]. 2011. [cit. 2012-03-15]. Available on-line: <http://www.economy.gov.sk/energeticka-politika-sr-5925/127610s>.

[3] PAVOlOVA, H., CSIKOSOVA, A., CUlKOVA, K., ANTOSOVA, M.: Efficiency of Pollutants Removal in Kosice Area with Respect of Living Qquality Increasing. Applied Mechanics and Materials, vol. 152-154 (2012), pp. 489-494. ISSN 1660-9336

[4] PAVOLOVA, H., SENOVA, A., BAKALAR, T.: Increase of Alternative and Renewable Energy Sources Utilization in Slovakia by 2020 in Comparison to other Selected EU Countries. Applied Mechanics and Materials, vol. 152-154 (2012), pp. 495-500. ISSN 1660-9336.

[5] Spotreba zemneho plynu na Slovensku vlani rastla [The Consumption of Natural Gas was Growing in Slovakia Last Year] [online]. 2011. Available on-line: 〈http://www.energia.sk/clanok/zemny-plyn/spotreba-zemneho-plynu-na-slovensku-vlani-rastla/3188/>.

[6] Elektrina vyrobena $\mathrm{z}$ obnovitelnych zdrojov [Electricity Produced from Renewable ources] Information available on-line: 〈http://www.statistics.sk/pls/eutab/html.h?ptabkod=tsdcc330>

[7] Narodny akcny plan pre energiu z obnovitelnych zdrojov [National Action Plan for Renewable Energy], Ministerstvo hospodarstva a vystavby SR. [online]. 2010. Available on-line: 〈www.economy.gov.sk/narodny-akcny-plan-pre-energiu-z-obnovitelnych-zdrojov>. 